\title{
Low-Input Production of Biomass from Perennial Grasses in the Coastal Plain of Georgia, USA
}

\author{
Joseph E. Knoll • William F. Anderson • \\ Timothy C. Strickland • Robert K. Hubbard • \\ Ravindra Malik
}

Published online: 6 April 2011

(C) The Author(s) 2011. This article is published with open access at Springerlink.com

\begin{abstract}
Warm-season perennial grasses are a promising source of biomass for energy production in Southeast USA, and low-input production is desirable. With only residual fertility in the soil and no irrigation, this test compared biomass yields of eight grasses under low-input production: L 79-1002 energycane (Saccharum hyb.), Merkeron and N51 napiergrass (Pennisetum purpureum Schum.), three clones of giant reed (Arundo donax L.), and two switchgrass (Panicum virgatum L.) lines. For the first 2 years napiergrass maintained dry matter (DM) yields over $25 \mathrm{Mg} \mathrm{DM} \mathrm{ha}{ }^{-1}$ year $^{-1}$, and energycane yielded over $20 \mathrm{Mg} \mathrm{DM} \mathrm{ha}{ }^{-1}$ year $^{-1}$ for 3 years. Switchgrass yields were lower $\left(8.6 \mathrm{Mg} \mathrm{DM} \mathrm{ha}{ }^{-1}\right.$ year $^{-1}$ average of 4 years), but the biomass contained less moisture at harvest than the other, larger-stemmed grasses. Switchgrass biomass also had the lowest concentrations of $\mathrm{N}, \mathrm{K}$, and ash. Average yields of giant reeds were also low $(6.4 \mathrm{Mg}$ $\mathrm{DM} \mathrm{ha}{ }^{-1}$ year $^{-1}$ ), while ash and $\mathrm{N}$ concentrations were relatively high compared with switchgrass and energycane. In 4 years of production, energycane and napiergrass removed between 269 and $386 \mathrm{~kg} \mathrm{~N} \mathrm{ha}^{-1}$ and $830-1,159 \mathrm{~kg} \mathrm{~K} \mathrm{ha}^{-1}$, while the other grasses removed significantly less of these nutrients. Giant reed removed $126 \mathrm{~kg} \mathrm{~N} \mathrm{ha}^{-1}$ and $193 \mathrm{~kg}$ $\mathrm{K} \mathrm{ha}^{-1}$, and switchgrass removed $83 \mathrm{~kg} \mathrm{~N} \mathrm{ha}^{-1}$ and $140 \mathrm{~kg}$
\end{abstract}

J. E. Knoll $(\bowtie) \cdot$ W. F. Anderson

USDA-ARS, Crop Genetics and Breeding Research Unit,

P.O. Box 748, Tifton, GA 31793, USA

e-mail: joe.knoll@ars.usda.gov

T. C. Strickland $\cdot$ R. K. Hubbard

USDA-ARS, Southeast Watershed Research Laboratory,

P.O. Box 748, Tifton, GA 31793, USA

R. Malik

Department of Natural Sciences, College of Sciences and Health

Professions, Albany State University,

Albany, GA 31705, USA
$\mathrm{K} \mathrm{ha}^{-1}$. In Southeast USA, it is possible to produce biomass from perennial grasses with minimal inputs but the high nutrient removal rates of some species suggest that it may not be sustainable for long periods of time.

Keywords Energycane - Giant reed · Napiergrass . Nitrogen $\cdot$ Switchgrass

\section{Introduction}

Warm-season perennial grasses have very good potential for production of biomass in Southeast USA. This region has warm summer temperatures and generally receives adequate, though sometimes erratic, rainfall. Perennial grasses, especially those which utilize the $\mathrm{C}_{4}$ photosynthetic pathway, should be able to take advantage of the warmer temperatures, and their deeper, more extensive root systems should allow them to continue growing during occasional droughts. Though initial establishment of perennial grasses may be more costly and energy intensive than planting conventional annual crops, a substantial reduction in costs and energy inputs over the longterm should be expected with perennials $[5,13]$. In addition, evidence suggests that perennial agriculture might have fewer negative impacts on the environment in terms of water consumption and quality, soil loss, and nutrient loss, compared with annual systems [9].

The milder winter temperatures in Southeast USA allow for the overwintering of subtropical grass species, including napiergrass (Pennisetum purpureum Schum.), and energycane (Saccharum hyb.), as well as the more temperate grass giant reed (Arundo donax L.). Napiergrass, also known as elephantgrass, is native to tropical Africa. In tropical and subtropical areas, it is an important forage species, which is capable of producing very high yields of biomass, even when 
grown on low-fertility soils [7]. Energycanes are derived from crosses between cultivated sugarcane (Saccharum officinarum L.) and related wild species (Saccharum spontaneum L.,Saccharum robustum Brandes \& Jesw ex. Grassl., Erianthus sp., etc.) and were selected specifically for the purpose of producing biomass for energy production. They generally have much higher fiber content and better cold tolerance than sugarcane varieties used for sucrose production [15]. Dry biomass yields exceeding $45 \mathrm{Mg} \mathrm{ha}^{-1}$ year $^{-1}$ have been reported for both napiergrass and energycane in Florida [24]. Giant reed is a large $C_{3}$ grass that is used for various purposes, including the production of reeds for musical instruments. This grass has recently gained attention as a potential bioenergy crop in southern Europe, where dry biomass yields over $37 \mathrm{Mg} \mathrm{ha}^{-1}$ year $^{-1}$ in well-fertilized plots have been reported $[2,17]$.

One potential drawback of exotic bioenergy crops is their potential to become troublesome invasive weeds. Native prairie grasses have been proposed as a low-input, ecologically sustainable source of biomass for much of the USA [10, 22]. Unlike exotic species, native plants are generally considered non-invasive, and they provide ideal habitat for wildlife. In addition, native grasses should require fewer inputs as they are already adapted to local conditions and disease pressures. Switchgrass (Panicum virgatum L.), a broadly adapted and long-lived perennial forage grass, has been extensively evaluated as a native biomass source in the USA [20, 22].

Because the per-unit value of biomass is low compared with food, feed, and fiber crops, production under minimal inputs is desirable for growers to profit from producing biomass. Additionally, production of biomass crops on socalled "marginal" lands has been proposed so that they do not compete with other crops for better farmland. The high yields reported above for napiergrass and energycane [24] and giant reed [2, [17] were obtained by applying ample amounts of fertilizer, irrigation, or both, but less is known about the yield potential of these grasses under less than ideal conditions, especially in Southeast USA, where soils are often of low fertility. Few studies have been conducted to compare the performance of different biomass feedstock species in the same field under low-input conditions. The purpose of this study was to evaluate and compare biomass yields and nutrient removal of eight perennial grasses under minimal inputs, with the aim of determining which species will be most productive in the Coastal Plain region of Georgia under such conditions over 4 years.

\section{Materials and Methods}

\section{Plant Material and Experimental Design}

The study was conducted at Tifton, GA, on a site comprised of two soils, an Alapaha loamy sand (Loamy, siliceous, subactive, thermic Arenic Plinthic Paleaquults) and a Clarendon loamy sand (fine-loamy siliceous semiactive thermic Plinthaquic Paleudult). In preceding years the site had been used for switchgrass breeding plots, and for annual grain crops before that, during which time adequate fertilization was applied and most of the crop residues were retained in the field. The study was initiated 2 Sept. 2005. Eight entries with potential for use in bioenergy production were included in this test: one energycane (L 79-1002; [4]), two napiergrasses (Merkeron and N51; [6]), two experimental lowland switchgrass lines (designated as PV-1 and $\mathrm{PV}-2$ ), and three giant reed clones (AD-S, AD-E, and ADF). The plots were laid out in a randomized complete block design with four replications. Two plots for each entry were located on soil mapped as Alapaha or Clarendon, with the following exceptions. Three plots of Merkeron were on Clarendon soil and one on Alapaha, and two plots (one $\mathrm{AD}-\mathrm{F}$ and one PV-2) were mapped as being equally split by Alapaha and Clarendon. Plots measured $3.7 \times 6 \mathrm{~m}$. Energycane and napiergrass were planted as stem cuttings, with two whole stems planted in each row, buried horizontally $10 \mathrm{~cm}$ deep, with rows spaced at $0.9 \mathrm{~m}$ apart (four rows per plot). The giant reeds were micropropagated transplants, derived from clones collected in the Southeast, and were planted $0.9 \mathrm{~m}$ apart in rows $0.9 \mathrm{~m}$ apart. Switchgrass was seeded in rows at $0.2 \mathrm{~m}$ apart, at a seeding rate of $11.2 \mathrm{~kg}$ seed $\mathrm{ha}^{-1}$. Irrigation was applied weekly during the first month of establishment, but was not applied afterwards. Weeds were controlled by mid-March applications of 2,4dichlorophenoxyacetic acid (2,4-D) and Surflan (United Phosphorus, Inc., Trenton, NJ) and manual cultivation as needed. No fertilizer was applied during the study.

\section{Biomass Harvest}

Total above-ground biomass was mechanically harvested after the first killing freeze of each year (Table 1) and removed from each plot. A sample from the center of each plot $(5 \times$ $1.2 \mathrm{~m}$ ) was weighed fresh, oven dried at $65^{\circ} \mathrm{C}$ until constant weight is reached, and then weighed again to determine percentages of moisture and DM. Samples of dried biomass were then ground in a Wiley mill to pass a $2-\mathrm{mm}$ screen prior to storage and further analyses.

\section{Biomass Nutrient Analyses}

Total $\mathrm{N}$ concentration in the dried plant samples were measured by dry combustion in a Vario EL-III Universal CHNOS Elemental Analyzer (Elementar Analysensysteme, Hanau, Germany) using approximately $5 \mathrm{mg}$ dried, ground tissue. Total ash concentration was determined by combustion in a Muffle furnace at $450^{\circ} \mathrm{C}$ for $6 \mathrm{~h}$. Potassium concentration was measured at the University of Georgia 
Table 1 Harvest dates and weather data recorded at Tifton, GA [8] during the study period

Growing degree days (GDD) were calculated between dates of last and first freeze with a base temperature of $15^{\circ} \mathrm{C}$. Date of first killing freeze is reached when the minimum air temperature $\leq 0^{\circ} \mathrm{C}$

\begin{tabular}{|c|c|c|c|c|c|c|}
\hline \multirow[b]{2}{*}{ Month } & \multicolumn{6}{|c|}{ Precipitation $(\mathrm{cm})$} \\
\hline & 2005 & 2006 & 2007 & 2008 & 2009 & 2010 \\
\hline Jan & - & 19.4 & 8.7 & 8.7 & 4.2 & 16.9 \\
\hline Feb & - & 10.3 & 5.7 & 19.9 & 5.5 & 8.5 \\
\hline Mar & - & 0.7 & 3.9 & 8.1 & 20.9 & 7.2 \\
\hline Apr & - & 4.3 & 1.1 & 7.7 & 21.0 & - \\
\hline May & - & 6.9 & 0.3 & 4.6 & 16.6 & - \\
\hline Jun & - & 10.6 & 14.9 & 5.8 & 5.0 & - \\
\hline Jul & - & 7.3 & 9.1 & 8.4 & 19.8 & - \\
\hline Aug & - & 7.2 & 17.7 & 31.3 & 17.8 & - \\
\hline Sep & 0.1 & 5.1 & 6.7 & 0.4 & 4.3 & - \\
\hline Oct & 1.5 & 2.9 & 7.7 & 16.3 & 10.2 & - \\
\hline Nov & 10.5 & 7.4 & 2.3 & 9.9 & 6.7 & - \\
\hline Dec & 12.6 & 14.3 & 14.4 & 7.9 & 19.3 & - \\
\hline Total (cm) & - & 96.4 & 92.5 & 128.8 & 151.2 & - \\
\hline GDD & - & 3,661 & 3,732 & 3,424 & 3,677 & - \\
\hline First freeze & $20 \mathrm{Dec}$ & $20 \mathrm{Nov}$ & $8 \mathrm{Nov}$ & 19 Nov & $21 \mathrm{Dec}$ & - \\
\hline Harvest & - & $5 \mathrm{Dec}$ & $11 \mathrm{Dec}$ & $9 \mathrm{Dec}$ & - & $3 \mathrm{Feb}$ \\
\hline
\end{tabular}

Agricultural and Environmental Services Laboratories (AESL) by inductively coupled plasma (ICP) spectrometry.

\section{Root and Soil Sampling and Analysis}

On 30 Apr 2009, a soil core (58-mm inside diameter) to a depth of $107 \mathrm{~cm}$ was collected from the center of each plot, immediately adjacent to a growing clump of grass using a hydraulic tractor-mounted soil probe (Giddings Machine Co. Fort Collins, CO). Three cores were also taken from the alleys between the plots (two on Clarendon soil and one on Alapaha) for comparison to bare soil. Four subsamples of each core $(0-15,30-45,60-76$, and 91-107 cm) were used to estimate root biomass and rooting depth. Roots were meticulously separated from soil samples by hand, and were then dried completely at $65^{\circ} \mathrm{C}$ in an oven. Pieces of rhizome (typically found in giant reeds) were not collected. Dried root samples were ground and analyzed for $\mathrm{C}$ and $\mathrm{N}$ concentration as for above-ground biomass. Samples of oven-dried soil were ground in a roller mill, and were also analyzed for $\mathrm{C}$ and $\mathrm{N}$ concentration by dry combustion. Potassium concentration in soil samples was determined by Mehlich I extraction followed by ICP spectrometry at the AESL.

\section{Statistical Procedures}

Data were analyzed using the GLIMMIX procedure in SAS v. 9.2 (SAS Institute, Cary, NC). Because of the perennial nature of the crops and the expected depletion of nutrient reserves over time, year was treated as a fixed factor. Replicates and soil type were treated as random factors. All tests were conducted at a probability level of $\alpha=0.05$. Tukey's HSD or the Tukey-Kramer procedure was used to test for significant differences between least-squares means estimates. Pearson correlations among biomass qualities were calculated using the CORR procedure.

\section{Results}

Large differences in DM yield were observed between entries, and changes in yields over the 4 years were also noted (Table 2). Overall, the highest yielding grasses were energycane $\mathrm{L}$ 79-1002 (18.7 $\mathrm{Mg} \mathrm{DM} \mathrm{ha}^{-1}$ ) and the two napiergrasses (16.4 $\mathrm{Mg} \mathrm{DM} \mathrm{ha}{ }^{-1}$ for Merkeron and 15.3 $\mathrm{Mg} \mathrm{DM} \mathrm{ha}{ }^{-1}$ for N51). Switchgrasses also had good yields, lower than napiergrass in the first year, but not significantly lower when averaged over 4 years $(8.6 \mathrm{Mg}$ $\mathrm{DM} \mathrm{ha}{ }^{-1}$ for both entries). Giant reeds had the lowest yields, but were not significantly different from switchgrass (Table 2). The energycane maintained yields above $20 \mathrm{Mg}$ $\mathrm{DM} \mathrm{ha}{ }^{-1}$ for the first three seasons and then declined in the fourth. Both napiergrasses yielded above $25 \mathrm{Mg} \mathrm{DM} \mathrm{ha}^{-1}$ for the first 2 years, then declined in the third and fourth seasons. By contrast, yields of giant reed and switchgrass peaked in the second season. Though significant, yield declines in the third and fourth seasons were much less pronounced in these species than in napiergrass or energycane. Yields of all entries were lowest in the 2009 season (Table 2).

Moisture concentration of freshly harvested biomass was also different among entries, which fell into three distinct groups (Table 3). Napiergrasses and energycane had the 
Table 2 Annual biomass yields of eight perennial grasses

Within columns, LS means with the same small letters are not significantly different. Yearly LS means with the same capital letters are not significantly different

\begin{tabular}{lllllll}
\hline \multicolumn{7}{c}{ Mg DM ha $^{-1}$} \\
\hline Species & Entry & 2006 & 2007 & 2008 & 2009 & 4-year LS mean \\
Energycane & L 79-1002 & $28.3 \mathrm{a}$ & $25.6 \mathrm{a}, \mathrm{b}$ & $21.0 \mathrm{a}$ & $8.1 \mathrm{a}$ & $18.7 \mathrm{a}$ \\
Giant Reed & AD-S & $5.3 \mathrm{~b}$ & $8.5 \mathrm{c}$ & $4.1 \mathrm{c}$ & $2.9 \mathrm{~b}$ & $4.8 \mathrm{c}$ \\
Giant Reed & AD-E & $6.8 \mathrm{~b}$ & $12.2 \mathrm{~b}, \mathrm{c}$ & $5.9 \mathrm{~b}, \mathrm{c}$ & $5.4 \mathrm{a}, \mathrm{b}$ & $7.2 \mathrm{c}$ \\
Giant Reed & AD-F & $7.0 \mathrm{~b}$ & $10.1 \mathrm{c}$ & $7.1 \mathrm{~b}, \mathrm{c}$ & $5.8 \mathrm{a}, \mathrm{b}$ & $7.3 \mathrm{c}$ \\
Napiergrass & Merkeron & $30.4 \mathrm{a}$ & $30.1 \mathrm{a}$ & $11.2 \mathrm{a}, \mathrm{b}$ & $7.1 \mathrm{a}$ & $16.4 \mathrm{a}, \mathrm{b}$ \\
Napiergrass & N51 & $36.3 \mathrm{a}$ & $27.4 \mathrm{a}, \mathrm{b}$ & $11.2 \mathrm{a}, \mathrm{b}$ & $5.0 \mathrm{a}, \mathrm{b}$ & $15.3 \mathrm{a}, \mathrm{b}$ \\
Switchgrass & PV-1 & $8.5 \mathrm{~b}$ & $12.9 \mathrm{~b}, \mathrm{c}$ & $7.9 \mathrm{~b}, \mathrm{c}$ & $6.4 \mathrm{a}, \mathrm{b}$ & $8.6 \mathrm{~b}, \mathrm{c}$ \\
Switchgrass & PV-2 & $9.4 \mathrm{~b}$ & $13.3 \mathrm{a}, \mathrm{b}, \mathrm{c}$ & $7.9 \mathrm{~b}, \mathrm{c}$ & $5.5 \mathrm{a}, \mathrm{b}$ & $8.6 \mathrm{~b}, \mathrm{c}$ \\
Yearly LS means & & $12.6 \mathrm{~A}$ & $15.8 \mathrm{~B}$ & $8.6 \mathrm{C}$ & $5.5 \mathrm{D}$ &
\end{tabular}

highest moisture concentration, ranging from 574 to $701 \mathrm{~g}$ $\mathrm{H}_{2} \mathrm{O} \mathrm{kg}^{-1}$ biomass. Giant reeds had intermediate moisture, ranging between 396 and $526 \mathrm{~g} \mathrm{H}_{2} \mathrm{O} \mathrm{kg}{ }^{-1}$ biomass, while switchgrass biomass had by far the lowest moisture at harvest, between 219 and $375 \mathrm{~g} \mathrm{H}_{2} \mathrm{O} \mathrm{kg} \mathrm{kg}^{-1}$ biomass. Moisture concentration of the energycane did not vary significantly over years, and relatively minor differences were noted for napiergrass and giant reed. Switchgrass, however, was considerably drier in the 2009 harvest than in previous years, likely from the delay in the date of harvest.

Ash concentration of the biomass, which ideally should be as low as possible for direct combustion and other thermal processes, was found to be highest in napiergrass and giant reed, averaging $46.2 \mathrm{~g}$ ash kg-1 DM. Energycane biomass had lower concentration of ash, averaging $34.4 \mathrm{~g}$ ash $\mathrm{kg}^{-1} \mathrm{DM}$ for the 4 years of the test. Switchgrass biomass had the lowest ash concentration. Ash concentra-

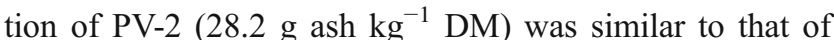
energycane, while PV-1 (23.1 $\mathrm{g}$ ash $\left.\mathrm{kg}^{-1} \mathrm{DM}\right)$ was significantly lower than energycane (Table 4). For the first 2 years, the overall mean ash concentration in harvested biomass did not change, but it decreased in each of the next two seasons.

The overall $\mathrm{N}$ concentration in harvested biomass showed a similar trend as ash (Table 5). In fact, these two factors were highly correlated $(R=0.694)$. Giant reeds tended to have the highest biomass $\mathrm{N}$ concentration, with a 4-year mean of $4.5 \mathrm{~g} \mathrm{~N} \mathrm{~kg}^{-1} \mathrm{DM}$. Napiergrass biomass $\mathrm{N}$ concentration was similar (3.7 $\left.\mathrm{g} \mathrm{N} \mathrm{kg}^{-1} \mathrm{DM}\right)$. Energycane biomass averaged $2.7 \mathrm{~g} \mathrm{~N} \mathrm{~kg}^{-1} \mathrm{DM}$, similar to switchgrass and N51 napiergrass. Switchgrass biomass averaged $2.1 \mathrm{~g}$ $\mathrm{N} \mathrm{kg}{ }^{-1} \mathrm{DM}$ over the 4 years of the test. The $\mathrm{K}$ concentration of harvested biomass also tended to decrease in the last two seasons (Table 6). Napiergrass appeared to take up an exceptionally large amount of $\mathrm{K}$ in the first growing season. In 2006 napiergrass biomass averaged $21 \mathrm{~g}$ $\mathrm{K} \mathrm{kg}^{-1} \mathrm{DM}$, much greater than any other species. In the following seasons napiergrass $\mathrm{K}$ concentration was more similar to that of the other grasses, but was still greater than that of switchgrass. Averaged over all 4 years, napiergrass and energycane biomass had the highest $\mathrm{K}$ concentrations (10.9 $\mathrm{g} \mathrm{K} \mathrm{kg}^{-1} \mathrm{DM}$ for napiergrass and $9.2 \mathrm{~g} \mathrm{~K} \mathrm{~kg}^{-1} \mathrm{DM}$ for energycane). Potassium concentration of giant reed biomass was intermediate $\left(6.6 \mathrm{~g} \mathrm{~K} \mathrm{~kg}^{-1} \mathrm{DM}\right)$, and that of switchgrass was lowest $\left(3.2 \mathrm{gK} \mathrm{kg}^{-1} \mathrm{DM}\right)$. Biomass $\mathrm{N}$ and $\mathrm{K}$ concentrations showed a moderate correlation $(R=$ $0.537)$, and as expected, $\mathrm{K}$ concentration was also correlated with ash concentration $(R=0.606)$. Net $\mathrm{N}$ and $\mathrm{K}$ removal at harvest were highest in the first 2 years following establishment for all species (Table 7). Annual
Table 3 Moisture concentration of freshly harvested biomass of eight perennial grasses

Within columns, LS means with the same small letters are not significantly different. Yearly LS means with the same capital letters are not significantly different

\begin{tabular}{|c|c|c|c|c|c|c|}
\hline \multirow[b]{2}{*}{ Species } & \multirow[b]{2}{*}{ Entry } & \multicolumn{4}{|c|}{$\mathrm{g} \mathrm{H}_{2} \mathrm{O} \mathrm{kg}^{-1}$ biomass } & \multirow[b]{2}{*}{ 4-year LS mean } \\
\hline & & 2006 & 2007 & 2008 & 2009 & \\
\hline Energycane & L 79-1002 & $642 \mathrm{a}$ & $591 \mathrm{~b}$ & $625 \mathrm{a}$ & 585 a & $611 \mathrm{a}$ \\
\hline Giant Reed & $\mathrm{AD}-\mathrm{S}$ & $526 \mathrm{~b}$ & $447 \mathrm{c}, \mathrm{d}$ & $492 \mathrm{~b}$ & $396 \mathrm{~b}$ & $465 \mathrm{~b}$ \\
\hline Giant Reed & AD-E & $475 \mathrm{~b}$ & $494 \mathrm{c}$ & $445 \mathrm{~b}$ & $402 \mathrm{~b}$ & $454 \mathrm{~b}$ \\
\hline Giant Reed & AD-F & $484 \mathrm{~b}$ & $478 \mathrm{c}$ & $447 \mathrm{~b}$ & $418 \mathrm{~b}$ & $457 \mathrm{~b}$ \\
\hline Napiergrass & Merkeron & $701 \mathrm{a}$ & $678 \mathrm{a}$ & $627 \mathrm{a}$ & 574 a & $645 \mathrm{a}$ \\
\hline Napiergrass & N51 & $686 \mathrm{a}$ & $664 \mathrm{a}, \mathrm{b}$ & 599 a & $580 \mathrm{a}$ & $632 \mathrm{a}$ \\
\hline Switchgrass & PV-1 & $375 \mathrm{c}$ & $364 d$ & $308 \mathrm{c}$ & $219 \mathrm{c}$ & $317 \mathrm{c}$ \\
\hline Switchgrass & PV-2 & $372 \mathrm{c}$ & $390 \mathrm{~d}$ & $321 \mathrm{c}$ & $227 \mathrm{c}$ & $328 \mathrm{c}$ \\
\hline Yearly LS means & & $533 \mathrm{~A}$ & $513 \mathrm{~A}$ & $483 \mathrm{~B}$ & $425 \mathrm{C}$ & \\
\hline
\end{tabular}


Table 4 Ash concentration in dry biomass of eight perennial grasses

Within columns, LS means with the same small letters are not significantly different. Yearly LS means with the same capital letters are not significantly different g ash $\mathrm{kg}^{-1} \mathrm{DM}$

\begin{tabular}{|c|c|c|c|c|c|c|}
\hline Species & Entry & 2006 & 2007 & 2008 & 2009 & 4-year LS mean \\
\hline Energycane & L 79-1002 & $36.0 \mathrm{~b}, \mathrm{c}$ & $45.3 \mathrm{a}, \mathrm{b}$ & $35.3 \mathrm{a}, \mathrm{b}$ & $24.3 \mathrm{~b}$ & $34.4 \mathrm{~b}$ \\
\hline Giant Reed & AD-S & $60.9 \mathrm{a}$ & 50.9 a & $48.6 \mathrm{a}$ & $38.2 \mathrm{a}$ & $49.0 \mathrm{a}$ \\
\hline Giant Reed & AD-E & $50.4 \mathrm{a}, \mathrm{b}$ & $50.5 \mathrm{a}$ & $48.1 \mathrm{a}$ & $34.1 \mathrm{a}, \mathrm{b}$ & $45.2 \mathrm{a}$ \\
\hline Giant Reed & AD-F & $50.0 \mathrm{a}, \mathrm{b}$ & $46.5 \mathrm{a}, \mathrm{b}$ & $49.0 \mathrm{a}$ & $35.8 \mathrm{a}, \mathrm{b}$ & $44.9 \mathrm{a}$ \\
\hline Napiergrass & Merkeron & $60.9 \mathrm{a}$ & $54.0 \mathrm{a}$ & $45.5 \mathrm{a}$ & $29.8 \mathrm{a}, \mathrm{b}$ & $45.9 \mathrm{a}$ \\
\hline Napiergrass & N51 & $58.8 \mathrm{a}$ & $48.1 \mathrm{a}, \mathrm{b}$ & $42.5 \mathrm{a}$ & $36.5 \mathrm{a}, \mathrm{b}$ & $45.8 \mathrm{a}$ \\
\hline Switchgrass & PV-1 & $24.1 \mathrm{c}$ & $32.3 \mathrm{~b}$ & $23.2 \mathrm{~b}$ & $15.8 \mathrm{c}$ & $23.1 \mathrm{c}$ \\
\hline Switchgrass & PV-2 & $35.0 \mathrm{~b}, \mathrm{c}$ & $40.4 \mathrm{a}, \mathrm{b}$ & $23.3 \mathrm{~b}$ & $19.2 \mathrm{c}$ & $28.2 \mathrm{~b}, \mathrm{c}$ \\
\hline \multicolumn{2}{|c|}{ Yearly LS means } & $45.0 \mathrm{~A}$ & $45.5 \mathrm{~A}$ & $37.8 \mathrm{~B}$ & $28.0 \mathrm{C}$ & \\
\hline
\end{tabular}

$\mathrm{N}$ removals ranged from 12 to $186 \mathrm{~kg} \mathrm{ha}^{-1}$ for napiergrass, 14-110 kg ha ${ }^{-1}$ for energycane, $14-47 \mathrm{~kg} \mathrm{ha}^{-1}$ for giant reeds, and 10-39 $\mathrm{kg} \mathrm{ha}^{-1}$ for the switchgrass. Similar patterns were observed in $\mathrm{K}$ removal: $37-698 \mathrm{~kg} \mathrm{ha}^{-1}$ for napiergrass, $55-350 \mathrm{~kg} \mathrm{ha}^{-1}$ for energycane, $20-83 \mathrm{~kg} \mathrm{ha}^{-1}$ for giant reed, and $11-78 \mathrm{~kg} \mathrm{ha}^{-1}$ for switchgrass.

In spring 2009, soil cores were taken in order to estimate root biomass and root distribution of these perennial grasses, and to determine whether there were speciesspecific effects on soil $\mathrm{K}$ content, or on soil $\mathrm{C}$ and $\mathrm{N}$ accretion. Roots were sampled at alternating depths in the soil cores $(0-15,30-45,60-76$, and 91-107 cm). Excluding rhizomes, the roots of giant reed were more evenly distributed throughout the sampled profile, while $60-78 \%$ of root biomass from energycane, napiergrass, and switchgrass was located in the top $15 \mathrm{~cm}$ of soil. Only one third of giant reed root biomass was located in this layer (Fig. 1). Based on soil bulk density, the total root biomass in each soil layer was calculated for each species. Estimates of total root biomass ranged between $3,684 \mathrm{~kg} \mathrm{DM} \mathrm{ha}{ }^{-1}$ for napiergrass to $5,956 \mathrm{~kg} \mathrm{DM} \mathrm{ha}^{-1}$ for switchgrass, though the differences between species were not statistically significant (Table 8). However, all species had greater root biomass than the bare soil samples taken from the alleys. While some roots were detected in the alleys, they probably originated from nearby plots. When root biomass was compared with harvested above-ground biomass in the year prior to collection of soil cores, significant differences were observed in the percentage of total plant biomass comprised in roots. Energycane roots comprised the lowest percentage of biomass (17.6\%) followed by napiergrass $(24.3 \%)$, switchgrass $(43.7 \%)$, and giant reeds (45.7\%; Table 8$)$. A complete census of roots and rhizomes at all depths would obviously have resulted in higher percentages of the total plant biomass. There were no differences between the four grass species or the bare soil control for soil $\mathrm{C}$ or $\mathrm{N}$ concentrations or total $\mathrm{C}$ or $\mathrm{N}$ pools (data not shown). However, in planted plots, from 1,536-2,901 kg C ha ${ }^{-1}$ and 16.4-28.3 $\mathrm{kg} \mathrm{N} \mathrm{ha}^{-1}$ were contained in the roots (Table 8). For all species, roots in the upper soil layer had higher nitrogen concentrations than deeper roots, despite differences in root distribution. Roots in the upper soil layer averaged $5.5 \mathrm{~g} \mathrm{~N} \mathrm{~kg}^{-1} \mathrm{DM}$, while roots in the three lower soil layers averaged 3.9, 3.4, and $4.2 \mathrm{~g} \mathrm{~N} \mathrm{~kg}^{-1} \mathrm{DM}$ by increasing depth. Differences between species in soil profile $\mathrm{K}$ content were observed. The total soil $\mathrm{K}$ in napiergrass and energycane plots was lower than that in switchgrass and giant reed plots, but was not different from the bare soil control (Fig. 2). However, the distribution of $\mathrm{K}$ in the bare soil profile was very different from planted plots. Soil K
Table 5 Nitrogen concentration in dry biomass of eight perennial grasses

Within columns, LS means with the same small letters are not significantly different. Yearly LS means with the same capital letters are not significantly different

\begin{tabular}{lllllll}
\hline \multicolumn{7}{c}{$\mathrm{g} \mathrm{N} \mathrm{kg}^{-1} \mathrm{DM}$} \\
\hline Species & Entry & 2006 & 2007 & 2008 & 2009 & 4-year LS mean \\
Energycane & L 79-1002 & $2.8 \mathrm{~b}, \mathrm{c}$ & $4.3 \mathrm{a}, \mathrm{b}, \mathrm{c}$ & $2.6 \mathrm{~b}, \mathrm{c}$ & $1.7 \mathrm{~b}$ & $2.7 \mathrm{~b}, \mathrm{c}$ \\
Giant Reed & AD-S & $6.9 \mathrm{a}$ & $4.5 \mathrm{a}, \mathrm{b}, \mathrm{c}$ & $4.3 \mathrm{a}, \mathrm{b}$ & $3.3 \mathrm{a}$ & $4.6 \mathrm{a}$ \\
Giant Reed & AD-E & $5.7 \mathrm{a}$ & $5.3 \mathrm{a}$ & $4.6 \mathrm{a}$ & $3.2 \mathrm{a}$ & $4.6 \mathrm{a}$ \\
Giant Reed & AD-F & $6.6 \mathrm{a}$ & $4.2 \mathrm{a}, \mathrm{b}, \mathrm{c}$ & $4.4 \mathrm{a}, \mathrm{b}$ & $2.9 \mathrm{a}, \mathrm{b}$ & $4.3 \mathrm{a}$ \\
Napiergrass & Merkeron & $6.1 \mathrm{a}$ & $5.3 \mathrm{a}$ & $3.9 \mathrm{a}, \mathrm{b}$ & $1.8 \mathrm{~b}$ & $3.8 \mathrm{a}$ \\
Napiergrass & N51 & $4.5 \mathrm{a}, \mathrm{b}$ & $5.2 \mathrm{a}, \mathrm{b}$ & $2.9 \mathrm{a}, \mathrm{b}$ & $2.3 \mathrm{a}, \mathrm{b}$ & $3.5 \mathrm{a}, \mathrm{b}$ \\
Switchgrass & PV-1 & $2.4 \mathrm{~b}, \mathrm{c}$ & $2.9 \mathrm{c}$ & $1.5 \mathrm{c}$ & $1.7 \mathrm{~b}$ & $2.1 \mathrm{c}$ \\
Switchgrass & PV-2 & $2.4 \mathrm{c}$ & $3.0 \mathrm{~b}, \mathrm{c}$ & $1.5 \mathrm{c}$ & $1.8 \mathrm{~b}$ & $2.1 \mathrm{c}$ \\
Yearly LS means & & $4.3 \mathrm{~A}$ & $4.2 \mathrm{~A}$ & $2.9 \mathrm{~B}$ & $2.3 \mathrm{C}$ & \\
\hline
\end{tabular}


Table 6 Potassium concentration in dry biomass of eight perennial grasses

\begin{tabular}{|c|c|c|c|c|c|c|}
\hline \multirow[b]{2}{*}{ Species } & \multirow[b]{2}{*}{ Entry } & \multicolumn{5}{|c|}{$\mathrm{g} \mathrm{K} \mathrm{kg}^{-1} \mathrm{DM}$} \\
\hline & & 2006 & 2007 & 2008 & 2009 & 4-year LS mean \\
\hline Energycane & L 79-1002 & $12.4 \mathrm{~b}$ & $8.9 \mathrm{a}, \mathrm{b}$ & $9.3 \mathrm{a}, \mathrm{b}$ & $6.9 \mathrm{a}$ & $9.2 \mathrm{a}$ \\
\hline Giant Reed & $\mathrm{AD}-\mathrm{S}$ & $9.8 \mathrm{~b}$ & $7.9 \mathrm{a}, \mathrm{b}$ & $6.5 \mathrm{a}, \mathrm{b}$ & $4.5 \mathrm{a}, \mathrm{b}$ & $6.9 \mathrm{~b}$ \\
\hline Giant Reed & AD-E & $7.9 \mathrm{~b}$ & $8.4 \mathrm{a}, \mathrm{b}$ & $6.0 \mathrm{~b}$ & $3.9 \mathrm{~b}$ & $6.3 \mathrm{~b}$ \\
\hline Giant Reed & $\mathrm{AD}-\mathrm{F}$ & $8.5 \mathrm{~b}$ & $8.1 \mathrm{a}, \mathrm{b}$ & $6.1 \mathrm{~b}$ & $4.9 \mathrm{a}, \mathrm{b}$ & $6.7 \mathrm{~b}$ \\
\hline Napiergrass & Merkeron & $21.3 \mathrm{a}$ & $10.6 \mathrm{a}$ & $10.2 \mathrm{a}$ & $6.1 \mathrm{a}, \mathrm{b}$ & 10.9 a \\
\hline Napiergrass & N51 & $20.7 \mathrm{a}$ & $11.2 \mathrm{a}$ & $9.4 \mathrm{a}, \mathrm{b}$ & $6.5 \mathrm{a}$ & $10.9 \mathrm{a}$ \\
\hline Switchgrass & PV-1 & $3.4 \mathrm{c}$ & $6.1 \mathrm{~b}$ & $2.6 \mathrm{c}$ & $1.8 \mathrm{c}$ & $3.1 \mathrm{c}$ \\
\hline Switchgrass & PV-2 & $3.5 \mathrm{c}$ & $5.8 \mathrm{~b}$ & $2.7 \mathrm{c}$ & $2.1 \mathrm{c}$ & $3.3 \mathrm{c}$ \\
\hline \multicolumn{2}{|c|}{ Yearly LS means } & $9.0 \mathrm{~A}$ & $8.2 \mathrm{~A}$ & $5.9 \mathrm{~B}$ & $4.1 \mathrm{C}$ & \\
\hline
\end{tabular}

Within columns, LS means with the same small letters are not significantly different. Yearly LS means with the same capital letters are not significantly different

was concentrated in the surface layer for all planted plots, but was evenly distributed through the profile in the bare soil control (Fig. 2).

\section{Discussion}

The high biomass yields observed for napiergrass and energycane in the first three seasons in this study are slightly lower than reports from Florida on well-fertilized and irrigated plots, where first year DM yields exceeded $45 \mathrm{Mg} \mathrm{ha}^{-1}$ [24]. However, the yields of these grasses are very consistent with other studies in which fertility was more limited. For example, on two low-fertility soils in Brazil, napiergrass averaged 26.3, 20.9, and $9.8 \mathrm{Mg}$ $\mathrm{DM} \mathrm{ha}{ }^{-1}$ in three successive harvests with no application of $\mathrm{N}$ fertilizer [7]. The authors attributed the yield decline to depletion of $\mathrm{N}$ from the soil. On a relatively fertile soil in Louisiana, L 79-1002 energycane yielded 22.2, 13.2, and

Table 7 Annual removal of $\mathrm{N}$ and $\mathrm{K}$ by biomass harvest of four perennial grass species

\begin{tabular}{lcclll}
\hline Species & 2006 & 2007 & 2008 & 2009 & Total \\
\hline \multicolumn{2}{l}{ N removal $\left(\mathrm{kg} \mathrm{N} \mathrm{ha}^{-1}\right)$} & & & & \\
Napiergrass & $186 \mathrm{a}$ & $150 \mathrm{a}$ & $38 \mathrm{a}, \mathrm{b}$ & $12 \mathrm{a}$ & $386 \mathrm{a}$ \\
Energycane & $91 \mathrm{a}$ & $110 \mathrm{a}$ & $54 \mathrm{a}$ & $14 \mathrm{a}$ & $269 \mathrm{a}$ \\
Giant Reed & $40 \mathrm{~b}$ & $47 \mathrm{~b}$ & $25 \mathrm{~b}$ & $14 \mathrm{a}$ & $126 \mathrm{~b}$ \\
Switchgrass & $22 \mathrm{c}$ & $39 \mathrm{~b}$ & $12 \mathrm{c}$ & $10 \mathrm{a}$ & $83 \mathrm{c}$ \\
K removal $\left(\mathrm{kg} \mathrm{K} \mathrm{ha}^{-1}\right)$ & & & & \\
Napiergrass & $698 \mathrm{a}$ & $314 \mathrm{a}$ & $110 \mathrm{a}$ & $37 \mathrm{a}$ & $1,159 \mathrm{a}$ \\
Energycane & $350 \mathrm{a}$ & $229 \mathrm{a}$ & $196 \mathrm{a}$ & $55 \mathrm{a}$ & $830 \mathrm{a}$ \\
Giant Reed & $55 \mathrm{~b}$ & $83 \mathrm{~b}$ & $35 \mathrm{~b}$ & $20 \mathrm{a}$ & $193 \mathrm{~b}$ \\
Switchgrass & $30 \mathrm{c}$ & $78 \mathrm{~b}$ & $21 \mathrm{~b}$ & $11 \mathrm{~b}$ & $140 \mathrm{c}$ \\
\hline
\end{tabular}

Within columns, LS means with the same letters are not significantly different
18.1 $\mathrm{Mg} \mathrm{DM} \mathrm{ha}{ }^{-1}$ for the first 3 years with no fertilization. It also continued to yield well for four additional years, though yields were still greater in fertilized treatments [4]. Yields of switchgrass in this study are slightly lower than those reported in the literature for lowland types on wellfertilized plots [20] but were generally consistent with yields reported for some unfertilized treatments on sandy soils [21, 23]. It has also been reported that switchgrass yields usually do not reach peak production in the first year [20], which is also consistent with observations in this study. Like switchgrass, giant reed has also been reported to establish more slowly, reaching peak yields in two or three

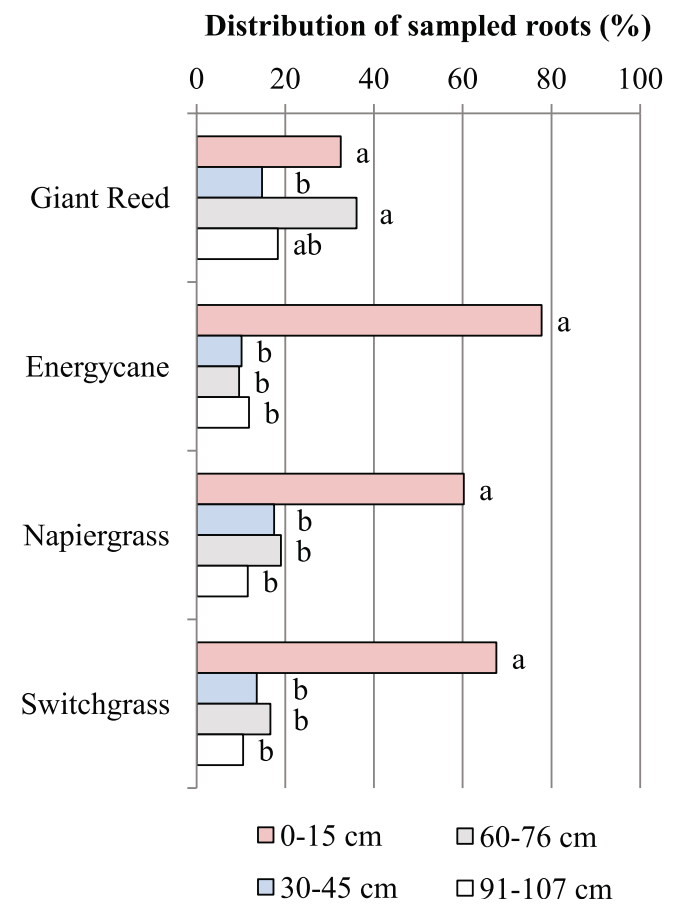

Fig. 1 Relative distributions of roots for four perennial grass species, sampled at four depths from soil cores taken in spring, 2009. Within species, means with the same letter are not significantly different 
Table 8 Root data from soil cores taken after 3 years of biomass production (sum of $0-15,30-45$, 60-76, and 91-107 cm layers)

Within columns, LS means with the same letters are not significantly different

\begin{tabular}{lllll}
\hline Species & $\mathrm{kg} \mathrm{roots} \mathrm{ha}^{-1}$ & Percent of 2008 DM in roots & $\mathrm{kg} \mathrm{C} \mathrm{ha}^{-1}$ in roots & $\mathrm{kg} \mathrm{N} \mathrm{ha}^{-1}$ in roots \\
\hline Energycane & $4,370 \mathrm{a}$ & $17.6 \mathrm{c}$ & $1,786 \mathrm{a}$ & $20.7 \mathrm{a}$ \\
Giant Reed & $4,557 \mathrm{a}$ & $45.7 \mathrm{a}$ & $2,271 \mathrm{a}$ & $27.7 \mathrm{a}$ \\
Napiergrass & $3,684 \mathrm{a}$ & $24.3 \mathrm{bc}$ & $1,536 \mathrm{a}$ & $16.4 \mathrm{a}$ \\
Switchgrass & $5,956 \mathrm{a}$ & $43.7 \mathrm{ab}$ & $2,901 \mathrm{a}$ & $28.3 \mathrm{a}$ \\
Bare soil & $388 \mathrm{~b}$ & - & $109 \mathrm{~b}$ & $2.3 \mathrm{~b}$ \\
\hline
\end{tabular}

seasons. However, biomass yields of giant reed observed in the present study were far lower than those reported in the literature $[2,17]$. The lack of applied fertilizer or other local growing conditions could partly explain this. Lack of water is probably not a factor, though, as rainfall was more plentiful in 2008 and 2009 than in the previous 2 years (Table 1), but yields declined. Average rainfall for Tifton (1961-1990) is around $122 \mathrm{~cm}_{\text {year }}{ }^{-1}$ [8]. The origin of the planting material (micropropagation) could also be a factor, or these particular genotypes may not be suited to the local conditions. Yield reduction in tissue culture-derived sugarcane compared with conventionally propagated sugarcane has been reported for some cultivars and tissue culture procedures [3, 11]; it is possible that similar effects occur in giant reed.

Net $\mathrm{N}$ removal at harvest was highest in the first 2 years following establishment for all species (Table 7). Sharp declines in N removal during 2008 preceded similarly sharp yield declines for energycane and napiergrass in 2009 (Table 2). Although the amounts of harvested $\mathrm{N}$ also declined for the giant reeds and switchgrasses following 2008, a similar large yield drop was not observed for these two species. Napiergrass removed approximately $374 \mathrm{~kg} \mathrm{~N}$ $\mathrm{ha}^{-1}$ and $1,121 \mathrm{~kg} \mathrm{~K} \mathrm{ha}^{-1}$ over the first 3 years. Energycane also took up a large amount of $\mathrm{N}\left(255 \mathrm{~kg} \mathrm{ha}^{-1}\right)$ and $\mathrm{K}$ (774 $\mathrm{kg} \mathrm{ha}^{-1}$ ) over the first 3 years (Table 7). While there were no apparent differences in the total soil $\mathrm{N}$ content in the cores taken after 3 years of production, evidence of $\mathrm{K}$ uptake by napiergrass and energycane was observed in the soil cores (Fig. 2). A moderate negative correlation $(R=$ $-0.498, p=0.004$ ) was observed between the amount of $\mathrm{K}$ removed in 3 years of production and the total remaining $\mathrm{K}$ detected in the profile. The distribution of $\mathrm{K}$ in the soil profiles shows evidence of $\mathrm{K}$ cycling by the perennial grasses [12]. Although some segments of the core were not sampled, and deeper sampling was not possible, these observations suggest that $\mathrm{K}$ is indeed being depleted primarily by uptake in napiergrass and energycane plots, and must be leaching from the bare soil control. Over 4 years, only $72 \mathrm{~kg} \mathrm{~N} \mathrm{ha}{ }^{-1}$ and $129 \mathrm{~kg} \mathrm{~K} \mathrm{ha}^{-1}$ were removed by switchgrass (Table 7 ). It is possible that the switchgrass plots in this study could maintain yields near current levels for several more years with no fertilizer application. In contrast, the large nutrient removals and sharp yield declines observed in the larger grasses suggest that subsequent fertilization will be needed to maintain high biomass production in these species.

Overall yields tended to decline in the third year (2008), and very low yields were observed for the entire test in 2009, despite the fact that more rain was received during this growing season than in the previous three, and the number of growing degree days was similar to the first two seasons (Table 1). Yield declines in the third and fourth seasons were most pronounced for the high-yielding energycane and napiergrass. Because these grasses removed very large quantities of both $\mathrm{N}$ and $\mathrm{K}$, the yield reductions observed in these grasses are most likely due to depletion of these nutrients from the soil. The declines in DM yield and in concentrations of $\mathrm{N}$ and $\mathrm{K}$ in harvested biomass in the last season might also suggest soil nutrient depletion, but because harvest was delayed into the winter, deterioration of biomass, nutrient translocation, and nutrient leaching from the senescent biomass could also partly explain these observations $[1,16]$.

The root profiles observed for napiergrass in this study agree with observations reported by Woodard and Prine

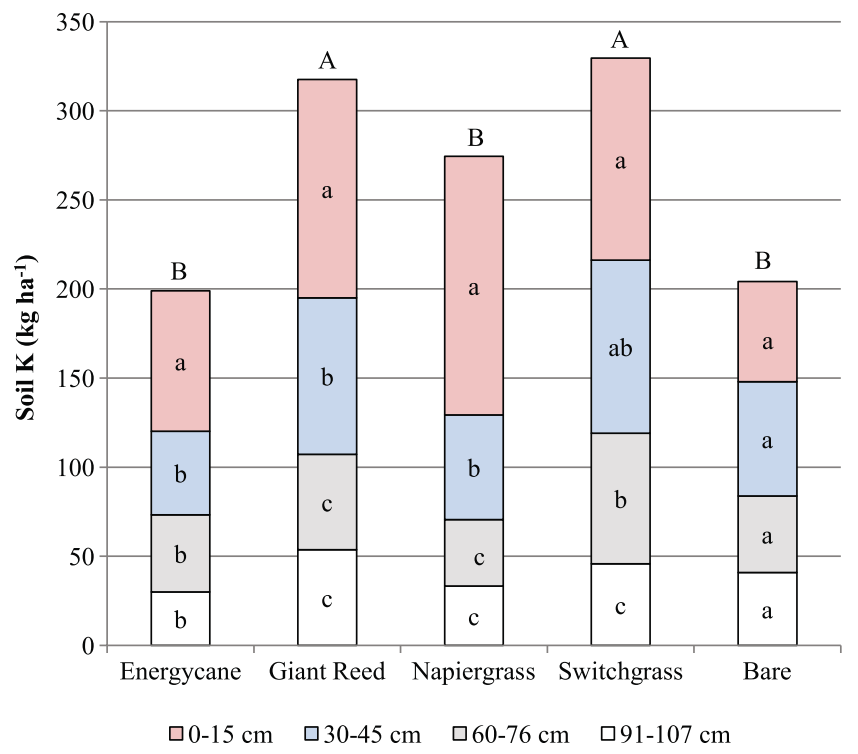

Fig. 2 Distribution of soil K (Mehlich I extractable) sampled at four depths in spring, 2009 under four perennial grass species and bare soil for comparison. Within species, means with the same small letter are not significantly different. Species totals with the same capital letter are not significantly different 
[24], who estimated that around $70 \%$ of the root biomass of napiergrass occurs in the top $25 \mathrm{~cm}$ of soil. Roots were also detected at the 91-107-cm depth for all accessions, but due to the difficulty in deeper sampling, it is not known just how far deeper they extend. Extraction of deep nutrient reserves could account for some of the high rates of $\mathrm{N}$ and $\mathrm{K}$ removal that were observed in the napiergrass and energycane plots. However, Woodard and Prine [24] also sampled only to a depth of $1 \mathrm{~m}$, so the importance of deeper roots is still unknown. Switchgrass roots are known to extend beyond 3-m depth in prairie soils [19], and sugarcane roots have been observed past $4.5 \mathrm{~m}$ less than a year after planting in Brazil [14]. It certainly seems possible that the grasses in this study were able to tap deep nutrient reserves. Deep rooting also supports our observation that these grasses, once established, were able to withstand prolonged dry periods with no irrigation.

\section{Conclusions}

For low-input biomass production in Southeast USA, napiergrass and energycane show the greatest yield potential. These species were able to produce high biomass yields the first and second years with no application of fertilizer or irrigation, though fertilization in subsequent years seems necessary to maintain yields. It appears that these grasses were able to efficiently tap the nutrients that had previously accumulated in the soil. The ability to take up large quantities of nutrients may be advantageous for certain locations. For example, napiergrass or energycane could be planted in buffers adjacent to heavily fertilized fields to control runoff of nutrients into groundwater [18], in addition to producing a useful biomass product. The lower nutrient removal rates for switchgrass and giant reed may suggest they are more suitable for upland production. In addition to high biomass yields, quick establishment is another considerable advantage of napiergrass and energycane, whereas giant reed and switchgrass require two or more seasons to reach peak yields. The higher moisture content of napiergrass, energycane, and giant reed present some challenges for efficient use and transportation of the harvested biomass. More research will be required to determine whether the higher dry matter production by napiergrass and energycane can offset the increased transportation costs and whether economical systems of drying, storage, or on-site pre-processing can be developed for this type of biomass. In this respect, switchgrass has a clear advantage, as it can dry considerably in the field after senescence. It also has lower $\mathrm{N}$ and ash concentrations than the other feedstocks in this test, except perhaps energycane. These characteristics make switchgrass preferable for direct combustion applications [1, 16]. The choice of which species to grow will obviously be determined by its intended application, logistical factors such as transportation costs, and external factors such as invasiveness. The results of this study also show that different perennial grass feedstock species will require specific production practices to remain sustainable for a prolonged period of time, and that conversion plant siting feasibility studies and economic analyses for long-term profitability should be based on productivity trials running at least 4 years. Soil C and N accretion studies for perennial grasses may need to be conducted over much longer periods of time.

Acknowledgments The authors would like to acknowledge Freddie Cheek, Tony Howell, Lorine Lewis, Bobby Shiver, and DeeAnne Webb for technical assistance. The authors would also like to thank Dr. Myron Parker (Prof. Emeritus, University of Georgia) and Dr. C. Corley Holbrook (USDA-ARS) for critical reviews of this manuscript.

Open Access This article is distributed under the terms of the Creative Commons Attribution Noncommercial License which permits any noncommercial use, distribution, and reproduction in any medium, provided the original author(s) and source are credited.

\section{References}

1. Adler PR, Sanderson MA, Boateng AA, Weimer PJ, Jung H-JG (2006) Biomass yield and biofuel quality of switchgrass harvested in fall or spring. Agron J 98:1518-1525

2. Angelini LG, Ceccarini L, Bonari E (2005) Biomass yield and energy balance of giant reed (Arundo donax L.) cropped in central Italy as related to different management practices. Eur J Agron 22:375-389

3. Bailey RA, Bechet GR (1989) A comparison of seedcane derived from tissue culture with conventional seedcane. Proc S Afr Sugar Technol Assoc 63:125-129

4. Bischoff KP, Gravois KA, Reagan TE, Hoy JW, Kimbeng CA et al (2008) Registration of 'L 79-1002' sugarcane. J Plant Regist 2:211-217

5. Boehmel C, Lewandowski I, Claupein W (2008) Comparing annual and perennial energy cropping systems with different management intensities. Agric Syst 96:224-236

6. Burton GW (1989) Registration of 'Merkeron' Napiergrass. Crop Sci 29:1327

7. de Morais RF, de Souza BJ, Leite JM, de Barros Soares LH, Alves BJR et al (2009) Elephant grass genotypes for bioenergy production by direct biomass combustion. Pesq Agropec Bras 44:133-140

8. GAEMN. Georgia Automated Environmental Monitoring Network. Available at: http://www.griffin.uga.edu/aemn/. Accessed 21 Dec 2010

9. Glover J (2003) Characteristics of annual vs perennial systems. In: Proceedings of the sod-based cropping system conference, University of Florida, Institute of Food and Agricultural Sciences, Quincy, FL, 20-21 Feb 2003

10. Gonzalez-Hernandez JL, Sarath G, Stein JM, Owens V, Gedye K, Boe A (2009) A multiple species approach to biomass production from native herbaceous perennial feedstocks. In Vitro Cell Devel Biol-Plant 45:267-281

11. Hoy JW, Bischoff KP, Milligan SB, Gravois KA (2003) Effect of tissue culture explant source on sugarcane yield components. Euphytica 129:237-240 
12. Jobbágy EG, Jackson RB (2004) The uplift of soil nutrients by plants: biogeochemical consequences across scales. Ecology 85:2380-2389

13. Karp A, Shield I (2008) Bioenergy from plants and the sustainable yield challenge. New Phytol 179:15-32

14. Laclau PB, Laclau JP (2009) Growth of the whole root system for a plant crop of sugarcane under rainfed and irrigated environments in Brazil. Field Crops Res 114:351-360

15. Legendre BL, Burner DM (1995) Biomass production of sugarcane cultivars and early-generation hybrids. Biomass Bioenergy 8:55-61

16. Lewandowski I, Kicherer A (1997) Combustion quality of biomass: Practical relevance and experiments to modify the biomass quality of Miscanthus $\times$ giganteus. Eur J Agron 6:163-177

17. Mantineo M, D'Agosta GM, Copani V, Patane C, Cosentino SL (2009) Biomass yield and energy balance of three perennial crops for energy use in the semi-arid Mediterranean environment. Field Crops Res 114:204-213

18. Mayer PM, Reynolds SK Jr, McCutchen MD, Canfield TJ (2007) Meta-analysis of nitrogen removal in riparian buffers. J Environ Qual 36:1172-1180
19. McLaughlin SB, Walsh ME (1998) Evaluating environmental consequences of producing herbaceous crops for bioenergy. Biomass Bioenergy 14:317-324

20. Mooney DF, Roberts RK, English BC, Tyler DD, Larson JA (2009) Yield and breakeven price of 'Alamo' switchgrass for biofuels in Tennessee. Agron J 101:1234-1242

21. Muir JP, Sanderson MA, Ocumpaugh WR, Jones RM, Reed RL (2001) Biomass production of 'Alamo' switchgrass in response to nitrogen, phosphorus, and row spacing. Agron J 93:896-901

22. Sanderson MA, Reed RL, McLaughlin SB, Wullschleger SD, Conger BV, Parrish DJ, Wolf DD, Taliaferro C, Hopkins AA, Ocumpaugh WR et al (1996) Switchgrass as a sustainable bioenergy crop. Bioresource Technol 56:83-93

23. Thomason WE, Raun WR, Johnson GV, Taliaferro CM, Freeman KW, Wynn KJ, Mullen RW (2004) Switchgrass response to harvest frequency and time and rate of applied nitrogen. J Plant Nutr 27:1199-1226

24. Woodard KR, Prine GM (1993) Dry-matter accumulation of elephantgrass, energycane, and elephantmillet in a subtropical climate. Crop Sci 33:818-824 